UDC 577.125.8:616.005

D. A. Dorovsky, A. L. ZagaYKo

National University of Pharmacy

\title{
ROLE OF LCAT ACTIVITY CHANGES IN ATHEROSCLEROSIS RISK
}

Lecithin cholesterol acyltransferase (LCAT) is a key enzyme that catalyzes the esterification of free cholesterol in plasma lipoproteins and plays a critical role in high density lipoprotein (HDL) metabolism. LCAT deficiency leads to accumulation of nascent pre-HDL due to impaired maturation of HDL particles, whereas enhanced expression is associated with the formation of large, apoE-rich HDL 1 particles. In addition to its function in HDL metabolism, LCAT was believed to be an important driving force behind macrophage reverse cholesterol transport (RCT) and, therefore, has been a subject of great interest in cardiovascular research since its discovery in 1962. Although half a century has passed, the importance of LCAT for atheroprotection is still under intense debate.

Key words: LCAT; atherosclerosis; lipoproteins

\section{LCAT STRUCTURE AND FUNCTION}

The human LCAT primarily produced by the liver, although it is also expressed in small amounts by intestine and in astrocytes in the brain, where it is involved in the cholesterol esterification in glia-derived apoE-containing lipoproteins $[20,24,39,41]$. The plasma concentration of LCAT is about $6 \mu \mathrm{g} / \mathrm{ml}$ and varies little in adult humans with age, gender, and smoking [1]. LCAT binds to lipoproteins and is primarily found in association with HDL, which likely prevents its uncontrolled clearance from the circulation [34]. The human LCAT half-life in plasma has been estimated to be 4-5 days [36] ApoAI is the most potent activator of LCAT, which enables it to synthesize cholesteryl esters from the free cholesterol on HDL by a transesterification reaction involving the transfer of a fatty acid at the $s n-2$ position of lecithin to the free hydroxyl group of cholesterol $[14,24]$. During this reaction, lecithins are converted into lysophosphatidylcholines. Firstly, apoAI concentrating the lipid substrates near LCAT and presenting it in an optimal conformation to LCAT. The conformation of these apoAI complexes is affected by the fluidity of the lipid bilayer $[27,35]$. The binding of LCAT to the apoAI is affected by the charge and size of the HDL particles [13]. The second step is the cleavage of the $s n$ -2 ester bond of lecithin, wich leads to the release of a fatty acyl [22]. This step is influenced by the LCAT phospholipase activity and depends on the lecithin composition [13]. The last step is the transacylation of the fatty acyl moiety to the sulfur atom of a cystein residue forming a thioester, which subsequently donates its fatty acyl to the 3 - -hydroxy group of the cholesterol molecule and forming cholesteryl ester [22]. Other apolipoproteins, such

(c) Dorovsky D. A., Zagayko A. I., 2016 as apoAII, apoCI-III, apoAIV, and apoE, also can activate LCAT, although with less efficiency [25].

Therefore, only a minor ammount of LCAT in the circulation can be found in binded to apoB-containing lipoproteins. In 1966, Glomset identified LCAT as an important driving force in the RCT pathway, a process that describes the HDL-mediated removal of excess cholesterol from peripheral tissues, including macrophages from the arterial wall, and subsequent delivery to the liver for biliary excretion. The first step of the RCT pathway involves production of apoAI in the liver or intestine and its further release into the plasma [32]. Interaction with ATP-binding cassette transporter (ABC)A1 primarily on the intestine and liver induces the formation of nascent discoidal HDL (ndHDL) particles that can stimulate cholesterol efflux from the macrophages in the arterial wall $[23,38]$. Upon association of cholesterol with the ndHDL particle, it is esterified by LCAT, leading to the conversion of the ndHDL into a more mature HDL 3 particle by partitioning of the cholesterol esters into the core of the particle. This particle gains the ability to induce the efflux of cellular cholesterol via ABCG1 and SR-BI [23, 38]. HDL particles being transformed into larger HDL 2 particles upon further enrichment with cholesteryl ester [32]. Several studies indicate that LCAT activity decreases correlatively with the enlargement of the HDL particle, particularly on large apoE-rich HDL 1 particles $[7,28,33,40]$. This could be explained by the fact that LCAT is subject to product inhibition [26], but it has also been suggested that sphingomyelin enrichment of HDL prevents binding of LCAT to the lipoprotein $[6,28]$. Notably, upon esterification of cholesterol in HDL, LCAT maintains the gradient of free cholesterol between the cellular membrane and the surface of the HDL particle, which is thought to pre- 
vent the transfer of cholesterol back to the cell by generating a continuous efflux of cholesterol from the cell to lipoproteins [12, 17, 31]. Importantly, the effect of LCAT on the flux of cholesterol may depend both on the environment of HDL in the extracellular medium and the type and metabolic status of the cells [16]. Therefore, in addition to its essential role in the first step of the RCT pathway, LCAT also enhances the delivery of cholesterol to the liver [16].

\section{LCAT AND ATHEROSCLEROSIS IN ANIMAL STUDIES}

Rabbits express CETP and can develop spontaneous atherosclerosis. Therefore, rabbits are often thought to be a better model for studying atherosclerosis than mice. In 1996, Hoeg et al. described the generation of transgenic New Zealand White rabbits with a $6.2 \mathrm{~kb}$ genomic fragment consisting of the entire human LCAT gene. To study the effects of human LCAT expression on atherosclerosis susceptibility, the rabbits were fed a daily ration of $120 \mathrm{~g}$ diet containing $0.3 \%$ cholesterol for a period of 17 weeks [21]. Plasma LCAT activity was $101 \pm 11 \mathrm{nmol} / \mathrm{ml} / \mathrm{h}$ in controls and $1.593 \pm 101 \mathrm{nmol} / \mathrm{ml} / \mathrm{h}$ in the transgenic rabbits on chow. On the cholesterol diet, LCAT activity remained more than 3 -fold that of controls. Total cholesterol and triglyceride levels were $28 \%$ and $24 \%$ lower, respectively, in the transgenic rabbits compared with controls. The reduction in total cholesterol was the consequence of a 2.6-fold decrease in non-HDL cholesterol levels, and HDL cholesterol was 5-fold higher. Quantification of atherosclerosis showed that $35 \pm 7 \%$ of the surface of the aortas of the control group were covered with lesions. For comparison, only $5 \pm 1 \%$ of the aortic surface in the LCAT transgenic rabbits was covered by lesions [21]. Overexpression of human LCAT thus protects against atherosclerosis in rabbits, probably due to the combined effect of the marked lowering of proatherogenic apoB-containing lipoproteins and the increase in HDL cholesterol. During the vivo kinetic experiments it was confirmed that LCAT increased the catabolism of apoB-containing lipoproteins, which was opposite to what was seen for apoAI catabolism [10]. To investigate the role of the LDL receptor in this enhanced catabolism, the LCAT transgenic rabbit was cross-bred with the Watanabe heritable hyperlipidemic (WHHL) rabbit with a lack of functional LDL receptors due to an amino acid deletion in the cysteine-rich ligand-binding domain of the protein [8, 9]. As expected, circulating LDL levels were markedly higher in rabbits lacking the LDL receptor. Interestingly, no lowering of LDL cholesterol was seen upon overexpression of LCAT. This relults might indicate that the enhanced catabolism of apoB-containing lipoproteins upon overexpression of LCAT is mediated via the LDL receptor. It must, however, be noted that the HDL cholesterol levels and LCAT activity was 5-fold lower in animals lacking the LDL receptor compared with controls [8]. Analysis of atherosclerosis at 22 months of age showed that in both WHHL rabbits and WHHL cont- rol rabbits overexpressing LCAT, $84 \pm 3 \%$ of the surface of the aorta was covered with lesions. This lack of protection despite the high HDL cholesterol levels is likely due to the overwhelming presence of apoB-containing lipoproteins in plasma. Furthermore, the massive lesion coverage of the aorta indicates that the disease was in a very advanced stage. It might be that different effects would have been found if the effects were determined at an earlier age.

The results of the mice studies differ signifcantly from the results shown in the rabbit studies. Although most of the rabbit studies largely confirm an antiatherogenic role for LCAT, mouse studies suggest an unanticipated proatherogenic role for LCAT in the development of atherosclerosis. In both models, it appears that the influence of LCAT on atherosclerosis mostly depends on its effects on proatherogenic apoB-containing lipoproteins. Furthermore, the effects found are highly dependent on the presence of additional key proteins involved in RCT, such as LDL receptor and CETP. Notably, viral overexpression of LCAT in nonhuman primates also resulted in an antiatherogenic profile characterized by decreased levels of apoB-containing lipoproteins and increased level of HDL cholesterol [3], similar to that observed in the transgenic rabbits.

\section{THERAPEUTIC REGULATION OF LCAT}

In the recent years, therapeutic upregulation of LCAT function has gained interest, not only as enzyme replacement therapy for LCAT deficiency syndromes but also as a potential new therapeutic strategy for reducing atherosclerosis. Strategies for therapeutically raising LCAT activity include small-molecule activators of LCAT, viral expression of LCAT, and recombinant LCAT protein administration. Van Craeyveld et al. investigated the effects of adenoviral LCAT overexpression in liver on established complex fiboratheromatous atherosclerotic lesions induced by feeding heterozygous LDL receptor knockout rabbits (62.5\% New Zealand White and $37.5 \%$ Japanese White) a $0.15 \%$ cholesterol diet for 420 days [37]. Non-HDL cholesterol was not affected whereas denoviral LCAT overexpression increased HDL cholesterol 1.9-fold. No significant effects were observed in the intima/media ratio, macrophage, collagen content, or smooth muscle cell compared with baseline at 120 days after gene transfer. However, the intima/media ratio was lower compared with the animals treated with an empty adenovirus, indicating that LCAT overexpression had the inhibiting effect on the progression of atherosclerosis. Adenoviral LCAT overexpression also induced cholesterol unloading of the lesions, consistent with enhanced RCT from the arterial wall [37], but considering the complex interaction of LCAT with lipoproteins in the circulation, extensive studies on the effects on atherosclerosis susceptibility should help us to draw any conclusions on the therapeutic applicability of these new studies. Intravenous infusion of recombinant LCAT in LCAT knockout mice with or without expression of human apoAI rapidly restored lipid abnormalities such as 
raised HDL cholesterol [34]. Furthermore, a preliminary report indicated that subcutaneous injection of recombinant LCAT attenuated atherosclerosis progression in New Zealand White rabbits and stimulated RCT [43]. Notably, a phase 1 clinical trial was announced recently in which the effects of intravenous recombinant human LCAT infusion (ACP-501) in subjects with coronary artery disease will be evaluated [2].

Small molecule activation of LCAT modulates lipoprotein metabolism

Specific LCAT activator increased LCAT activity in vitro in plasma from mouse, rhesus monkey, hamster, and human.

$\mathrm{C} 57 \mathrm{Bl} / 6$ mice and hamsters received a single dose (20 mg/kg) of LCAT activator to assess the acute pharmacodynamic effects of LCAT activator. Both species displayed significant decrease in triglycerides and non-HDLc and a significant increase in high-density lipoprotein cholesterol (HDLc) acutely after dosing. To examine LCAT activator's chronic effect on lipoprotein metabolism, during the period of two weeks hamsters received a daily dosing of vehicle or of 20 or $60 \mathrm{mg} / \mathrm{kg}$ of LCAT activator. Activator treatment resulted in a significant reduction in very low-density lipoprotein cholesterol and asignificant increase HDL particle size, in amount of HDLc, plasma apolipoprotein A-I level, and plasma cholesteryl ester (CE) to free cholesterol ratio. Triglycerides trended toward a dose-dependent decrease in very low-density lipoprotein and HDL, with multiple triglyceride species reaching statistical significance. The increase in plasma CE resulted the increase in HDL CE. Gallbladder bile acids content displayed the more than 2 -fold increase with the $60 \mathrm{mg} / \mathrm{kg}$ treatment. Plasma LCAT was activated from multiple species in vitro LCAT activator was spiked into plasma from C57Bl/ 6 mouse, rhesus monkey, hamster, and human at different concentrations.

To assess the effects of chronic activation of LCAT by by small molecule activator on lipoprotein metabolism, vehicle control ( $0.5 \%$ methyl cellulose), LCAT activator at $60 \mathrm{mg} / \mathrm{kg}$, or LCAT activator at $20 \mathrm{mg} / \mathrm{kg}$ was administered by oral gavage daily into high fat diet-fed hamsters for 14 days. LCAT activator treatment resulted in a significant dose-dependent increase in plasma CE and plasma $\mathrm{CE} / \mathrm{FC}$ ratio and increase in plasma $\mathrm{TC}$ and plasma $\mathrm{FC}$. Plasma LysoPC displayed a significant increase at both doses. Plasma PC showed no significant difference for both doses. Plasma TG showed a trend toward a dose-dependent decrease without reaching statistical significance. LCAT activator treatment also resulted in a significant significant decrease in VLDL cholesterol (VLDLc) and a significant increase in HDLc at both doses, whereas LDL cholesterol (LDLc) level remained unchanged. The FPLC analysis revealed a dose-dependent leftward shift of the HDL peaks, indicating that LCAT activator treatment resulted in a significant, dose-dependent increase in HDL particle size. Plasma apoA-I was significantly increased at both doses, whereas plasma apoB was unchanged.
In genetic or somatic LCAT overexpression models, including those in higher animal species, LCAT gain of function is associated with increased HDLc wich consistent with an antiatherosclerotic benefit $[5,42]$. LCAT activator enhanced plasma LCAT activity with micromolar potency (EC50 range of 1-10 $\mu \mathrm{mol} / \mathrm{L}$ for all d6-CEproducts). It had been postulated that this activity increase was induced by interacting with the free sulfhydryl group in cysteine (C)31 near its catalytic site. C31 appears to be a conserved residue in LCAT from multiple species. Observation of the similar activity of LCAT activator across multiple species proves that LCAT activator is acting via a similar mechanism in all species from the study. It also has been shown that LCAT from baboon and hamster has similar positional specificity and substrate as human LCAT, in contrast to the mouse [30]. For in vivo characterization, an acute single-dose experiment was conducted in $\mathrm{C} 57 \mathrm{Bl} / 6$ mice to establish a relationship between downstream plasma lipid profile (pharmacodynamics) and target engagement (activation of LCAT). After a single dose of LCAT activator $(20 \mathrm{mg} / \mathrm{kg})$, the increase in ex vivo plasma LCAT activity within 1 to 5 hours following dosing correlated with changes in HDL particle size, CE/FC ratio and plasma HDLc levels. The "rebound" of non- HDL at 24 to 48 hours suggests that chronic treatment with LCAT activator in $\mathrm{C} 57 \mathrm{Bl} / 6$ mice may result in increased non-HDL. It had been reported that LCAT transgenic mouse had increased non-HDL and exacerbated atherosclerosis, whereas further introduction of CETP transgene decreased non-HDL and reduced atherosclerosis in the LCAT transgenic background $[4,15]$. Analysis of downstream pharmacodynamics markers revealed a significant reduction in non-HDLc and TG in the early time points and a significant increase in HDLc throughout the time course, which tracked with the changes in LCAT activity increase and suggest that the effects on lipids were likely due to LCAT activation by small putative activator. Observation on non-HDL suggests that CETP needs to be present to extrapolate effects of LCAT activation to human. The above results establish a relationship between pharmacodynamic markers and target engagement under acute conditions and are consistent with the current understanding of the role of LCAT in RCT and HDL metabolism. Therefore, a chronic study in hamsters was pursued to characterize the effect of LCAT activation by small molecule activator on lipid profiles in detail. A significant increase in HDL particle size, HDLc level and plasma apoA-I level was observed as well as dose-dependent decreases in multiple TG species and VLDLc. Low-density lipoprotein cholesterol remained the same, possibly because the baseline LDL level in this model is modest and thus givesa small window for reduction. Epidemiological studies have suggested that increased HDLc, decreased VLDLc, and decreased plasma TG are all associated with risk reduction for atherosclerosis [19]. In addition, increased plasma apoA-I level and lipid-rich, large HDL particle are also associated with re- 
duced risk for coronary heart disease $[11,18,19]$. The global changes in the lipoprotein can potentially be atheroprotective. Additional analyses indicated that liver microsomal stability and the plasma stability of LCAT activator were poor, which indicates the short duration of LCAT activation observed ex vivo. Nonetheless, the correlation between and LCAT activity and pharmacodynamic markers strongly supports the conclusion that small molecule activators elicited global changes in lipoprotein metabolism via activation of LCAT. In summary, the results from the current study demonstrate that activation of LCAT via these molecules produces concomitant changes in the lipoprotein profile in hamsters and mice and raise the possibility for small molecule therapeutic intervention of atherosclerosis and dyslipidemia via modulating LCAT activity. The findings of decreased TG and enhanced HDLc are are in line with observations from humans with LCAT deficiency and consistent with previous LCAT overexpression studies in higher animal species. This similarity between the LCAT-deficient human phenotype and the preclinical findings offers the possibility that the changes induced by a LCAT activator might translate into humans, and the finding of decreased VLDL may translate into decreased LDL in human. The detailed characterization from the current study of lipoprotein particle composition also sheds new light on LCAT's mechanism of action in lipoprotein metabolism.

\section{CONCLUSIONS}

Although a half a century of extensive research has passed since the discovery of LCAT as a key enzyme in the esterification of cholesterol in 1962, it has not (yet) fulfilled the promise as a new therapeutic target for atherosclerosis. Over the years, many studies have been performed investigating the role of LCAT in atherosclerosis in animal models and humans, with many conflicting data as a result. From the animal studies, it can be concluded that the effects of LCAT on atherosclerosis and lipoprotein metabolism largely depend on the animal model used and the presence of additional proteins involved in the RCT pathway, like LDL receptor and CETP. All the studies performed during the last 50 years have made it clear that LCAT plays a role in the pathogenesis of atherosclerosis. Newly developed activator(s) of endogenous LCAT, recombinant LCAT and small putative molecules LCAT activators infusions in humans and animals will provide valuable information to establish whether targeting of LCAT is a promising therapeutic strategy to reduce cardiovascular risk.

\section{REFERENCES}

1. Albers J. J. Population-based reference values for lecithin-cholesterol acyltransferase (LCAT) / [J. J. Albers, R. O. Bergelin, J. L., Adolphson et al.] // Atherosclerosis. - 1982. - Vol. 43. - P. 369-379.

2. Alphacore Pharma LLC. 2012. Effect of ACP-501 on safety, tolerability, pharmacokinetics and pharmaco- dynamics in subjects with coronary artery disease. ClinicalTrials.gov Identifier: NCT01554800. Available at: http://clinicaltrials.gov/ct2/show/ NCT01554800. Accessed April 20, 2012.

3. Amar M. J. Adenoviral expression of human lecithincholesterol acyltransferase in nonhuman primates leads to an antiatherogenic lipoprotein phenotype by increasing high-density lipoprotein and lowering low-density lipoprotein / [M. J. Amar, R. D. Shamburek, B. Vaisman et al.] // Metabolism. - 2009. - Vol. 58. - P. 568-575.

4. Berard A. M. High plasma HDL concentrations associated with enhanced atherosclerosis in transgenic mice overexpressing lecithin-cholesteryl acyltransferase / [A. M. Berard, B. Foger, A. Remaley et al.] // Nat. Med. - 1997. - Vol. 3. - P. 744-749.

5. Berard A.M. Overexpression of lecithin cholesterol acyltransferase in transgenic rabbits prevents dietinduced atherosclerosis / [A. M. Berard, J. F. Cornhill, E. E. Herderick et al.] // Proc. Natl. Acad. Sci. USA. 1996. - Vol. 93. - P. 11448-11453.

6. Bolin D. J. Sphingomyelin inhibits the lecithincholesterol acyltransferase reaction with reconstituted high density lipoproteins by decreasing enzyme binding / D. J. Bolin, A. Jonas // J. Biol. Chem. - 1996. - Vol. 271. P. 19152-19158.

7. Bouly M. Induction of the phospholipid transfer protein gene accounts for the high density lipoprotein enlargement in mice treated with fenofi brate / [M. Bouly X. C. Jiang, C. Fievet et al.] // J. Biol. Chem. - 2001. Vol. 276. - P. 25841-25847.

8. Brousseau M. E. Correction of hypoalphalipoproteinemia in LDL receptordeficient rabbits by lecithin cholesterol acyltransferase / [M. E. Brousseau, J. Wang, S. J. Demosky et al.] // J. Lipid Res. - 1998. - Vol. 39. P. 1558-1567.

9. Brousseau M. E. LCAT modulates atherogenic plasma lipoproteins and the extent of atherosclerosis only in the presence of normal LDL receptors in transgenic rabbits / [M. E. Brousseau, R. D. Kauffman, E. E. Herderick et al.] // Arterioscler. Thromb. Vasc. Biol. 2000. - Vol. 20. - P. 450-458.

10. Brousseau M. E. Overexpression of human lecithin cholesterol acyltransferase in cholesterol-fed rabbits: LDL metabolism and HDL metabolism are affected in a gene dose-dependent manner / [M. E. Brousseau, B. L. Vaisman, A. M. Bérard et al.] // J. Lipid Res. 1997. - Vol. 38. - P. 2537-2547.

11. Contois J. Reference intervals for plasma apolipoprotein A-1 determined with a standardized commercial immunoturbidimetric assay: results from the Framingham Offspring Study / [J. Contois, J. R. McNamara, C. Lammi-Keefe et al.]// Clin. Chem. - 1996. Vol. 42. - P. 507-514.

12. Czarnecka H. Regulation of cellular cholesterol efflux by lecithin cholesterol acyltransferase reaction through nonspecific lipid exchange / H. Czarnecka, S. Yokoyama // J. Biol. Chem. - 1996. - Vol. 271. - P. 2023-2028. 
13. Dobiásová M. Advances in understanding of the role of lecithin cholesterol acyltransferase (LCAT) in cholesterol transport / M. Dobiásová, J. J. Frohlich // Clin. Chim. Acta. - 1999. - Vol. 286. - P. 257-271.

14. Fielding C. J. Molecular physiolology of reverse cholesterol transport / C. J. Fielding, P. E. Fielding // J. Lipid Res. - 1995. - Vol. 36. - P. 211-228.

15. Foger B. Cholesteryl ester transfer protein corrects dysfunctional high density lipoproteins and reduces aortic atherosclerosis in lecithin cholesterol acyltransferase transgenic mice / [B. Foger, M. Chase, M. J. Amar etal.] //J. Biol.Chem. - 1999. -Vol.274.-P.36912-36920.

16. Fournier N. Fractional efflux and net change in cellular cholesterol content mediated by sera from mice expressing both human apolipoprotein $\mathrm{AI}$ and human lecithin:cholesterol acyltransferase genes / [N. Fournier, V. Atger, J. P. Paul et al.] // Atherosclerosis. 1999. - Vol. 147. - P. 227-235.

17. Glomset J. A. The plasma lecithin cholesterol acyltransferase reaction / J. A. Glomset// J. Lipid Res. 1968. - Vol. 9. - P. 155-167.

18. Gordon T. High density lipoprotein as a protective factor against coronary heart disease / [T. Gordon, W. P. Castelli, M. C. Hjortland et al.] // The Framingham Study. Am. J. Med. - 1977. - Vol. 62. - P. 707-714.

19. Havel R. J. High-density lipoproteins, cholesterol transport and coronary heart disease / R. J. Havel // Circulation. - 1979. - Vol. 60. - P. 1-3.

20. Hirsch-Reinshagen V. LCAT synthesized by primary astrocytes esterifies cholesterol on glia-derived lipoproteins/ [V. Hirsch-Reinshagen, J. Donkin, S. Stukas et al.] // J. Lipid Res. - 2009. - Vol. 50. - P. 885-893.

21. Hoeg J. M. Overexpression of lecithin: cholesterol acyltransferase in transgenic rabbits prevents diet-induced atherosclerosis/ [J. M. Hoeg, S. Santamarina-Fojo, A. M. Bérard et al.] // Proc. Natl. Acad. Sci. USA. 1996. - Vol. 93. - P. 11448-11453.

22. Jauhiainen M. Human plasma lecithincholesterol acyltransferase. An elucidation of the catalytic mechanism / M. Jauhiainen, P. J. Dolphin // J. Biol. Chem. 1986. - Vol. 261. - P. 7032-7043.

23. Jessup W. Roles of ATP binding cassette transporters A1 and G1, scavenger receptor BI and membrane lipid domains in cholesterol export from macrophages / [W. Jessup, I. C. Gelissen, K. Gaus et al.] // Curr. Opin. Lipidol. - 2006. - Vol. 17. - P. 247-257.

24. Jonas A. Lecithin cholesterol acyltransferase // Biochim. Biophys. Acta. - 2000. - Vol. 1529. - P. 245-256.

25. Jonas A. Lecithin-cholesterol acyltransferase in the metabolism of high-density lipoproteins // Biochim. Biophys. Acta. - 1991. - Vol. 1084. - P. 205-220.

26. Kosek A. B. Binding affinity and reactivity of lecithin cholesterol acyltransferase with native lipoproteins/ A. B. Kosek, D. Durbin, A. Jonas // Biochem. Biophys. Res. Commun. - 1999. - Vol. 258. - P. 548-551.

27. Laccotripe M. The carboxyl-terminal hydrophobic residues of apolipoprotein A-I affect its rate of phos- pholipid binding and its association with high density lipoprotein / [M. Laccotripe, S. C. Makrides, A. Jonas et al.] // J. Biol. Chem. - 1997. - Vol. 272. P. 17511-17522.

28. Lee J. Y. Functional LCAT deficiency in human apolipoprotein A-I transgenic, SR-BI knockout mice / [J. Y. Lee, R. M. Badeau, A. Mulya et al.] // J. Lipid Res. - 2007. - Vol. 48. - P. 1052-1061.

29. Lee J. Y. Functional LCAT deficiency in human apolipoprotein A-I transgenic, SR-BI knockout mice / [J. Y. Lee, R. M. Badeau, A. Mulya et al.] // J. Lipid Res. - 2007. - Vol. 48. - P. 1052-1061.

30. Liu M. Specificity of lecithin cholesterol acyltransferase and atherogenic risk: comparative studies on the plasma composition and in vitro synthesis of cholesteryl esters in 14 vertebrate species / M. Liu, J. D. Bagdade, P. V. Subbaiah / / J. Lipid. Res. - 1995. - Vol. 36. P. 1813-1824.

31. Murphy J. R. Erythrocyte metabolism. IV. Equilibration of cholesterol-4-C-14 between erythrocytes and variously treated sera / J. R. Murphy // J. Lab. Clin. Med. - 1962. - Vol. 60. - P. 571-578.

32. Ohashi R. Reverse cholesterol transport and cholesterol effl ux in atherosclerosis / [R. Ohashi, X. Wang, Q. Yao et al.] // QJM. - 2005. - Vol. 98. - P. 845-856.

33. Oliveira H. C. Cholesteryl ester transfer protein activity enhances plasma cholesteryl ester formation. Studies in CETP transgenic mice and human genetic CETP deficiency / [H. C. Oliveira, R. Milne, S. M. Marcovina et al.] // Arterioscler. Thromb. Vasc. Biol. 1997. - Vol. 17. - P. 1045-1052.

34. Rousset X. Effect of recombinant human lecithin cholesterol acyltransferase infusion on lipoprotein metabolism in mice / [X. Rousset, B. Vaisman, R. Homan et al.] // J. Pharmacol. Exp. Ther. - 2010. - Vol. 335. - P. 140-148.

35. Sparks D. L. Effect of the surface lipid composition of reconstituted LPA-I on apolipoprotein A-I and lecithin: cholesterol acyltransferase activity / D. L. Sparks, P. G. Frank, T. A. Nevill // Biochim. Biophys. Acta. 1998. - Vol. 1390. - P. 160-172.

36. Stokke K. T. Familial lecithin cholesterol acyltransferase deficiency. Studies on lipid composition and morphology of tissues / [K. T. Stokke, K. S. Bjerve, J. P. Blomhoff et al.] // Scand. J. Clin. Lab. Invest. Suppl. - 1974. - Vol. 137. - P. 93-100.

37. Van Craeyveld E. Apolipoprotein A-I and lecithin cholesterol acyltransferase transfer induce cholesterol unloading in complex atherosclerotic lesions / [E. Van Craeyveld, J. Lievens, F. Jacobs et al.] // Gene Ther. 2009. - Vol. 16. - P. 757-765.

38. Van Eck M. Scavenger receptor BI and ATP-binding cassette transporter A1 in reverse cholesterol transport and atherosclerosis / [M. Van Eck, M. Pennings, M. Hoekstra et al.] // Curr. Opin. Lipidol. - 2005. Vol. 16. - P. 307-315.

39. Warden C. H. Tissue-specific expression, developmental regulation, and chromosomal mapping of the le- 
cithin: cholesterol acyltransferase gene. Evidence for expression in brain and testes as well as liver / [C. H. Warden, C. A. Langner, J. W. Taylor et al.] // J. Biol. Chem. - 1989. - Vol. 264. - P. 21573-21581.

40. Yamashita S. Accumulation of apolipoprotein E-rich high density lipoproteins in hyperalphalipoproteinemic human subjects with plasma cholesteryl ester transfer protein defi ciency / [S. Yamashita, D. L. Sprecher, N. Sakai et al.] // J. Clin. Invest. - 1990. - Vol. 86. P. 688-695.

41. Yang C. Y. Lecithin:cholesterol acyltransferase. Functional regions and a structural model of the enzyme /
[C. Y. Yang, D. Q. Pao Manoogian, F. S. Lee et al.] // J. Biol. Chem. - 1987. - Vol. 262. - P. 3086-3091.

42. Zhang A. H. Increased plasma HDL cholesterol levels and biliary cholesterol excretion in hamster by LCAT overexpression / [A. H. Zhang, S. Gao, J. L. Fan et al.] // FEBS Lett. - 2004. - Vol. 570. - P. 25-29.

43. Zhou M. Lecithin cholesterol acyltransferase promotes reverse cholesterol transport and attenuates atherosclerosis progression in New Zealand White Rabbits / [M. Zhou, J. Sawyer, K. Kelley et al.] // (Abstract 5920) Circulation. - 2009. - Vol. 120. P. S1175. 


\section{УДК 577.125.8:616.005}

\section{Д. А. Доровський, А.Л. Загайко}

РОЛЬ ЛХАТ У ЗНИЖЕННІ РИЗИКУ РОЗВИТКУ АТЕРОСКЛЕРОЗУ

Лецитин холестерол ацилтрансфераза (ЛХАТ) $є$ ключовим ферментом, що каталізує етерифікацію вільного холестеролу в ліпопротеїнах плазми і відіграє винятково важливу роль у метаболізмі ліпопротеїнів високої щільності (ЛПВЩ). Дефіцит ЛХАТ призводить до накопичення часток-попередників ЛПВЩ через уповільнення їх дозрівання, тоді як посилена експресія ЛХАТ сприяє формуванню великих, аполіпопротеїн Е-збагачених ЛПВЩ 1 часток. Цей фермент також $є$ важливою рушійною силою в зворотному транспорті холестеролу макрофагами, тому він завжди привертав увагу вчених, які займаються дослідженнями серцево-судинних захворювань.

Ключові слова: ЛХАТ; атеросклероз; ліпопротеїни

\section{УДК 577.125.8:616.005}

Д. А. Доровский, А.Л. Загайко

РОЛЬ ЛХАТ В СНИЖЕНИИ РИСКА РАЗВИТИЯ АТЕРОСКЛЕРОЗА

Лецитин холестерол ацилтрансфераза (ЛХАТ) является ключевым ферментом, катализирующим эстерификацию свободного холестерола в липопротеинах плазмы и играет исключительную роль в метаболизме липопротеинов высокой плотности (ЛПВП). Дефицит ЛХАТ приводит к накоплению возникающих частиц-предшественников ЛПВП в связи с замедлением их созревания, тогда как усиленная экспрессия ЛХАТ способствует формированию больших, аполипопротеин Е-обогащенных ЛПВП 1 частиц. В дополнение к функции ЛХАТ в метаболизме ЛПВП этот фермент также является важной движущей силой в обратном транспорте холестерола макрофагами, поэтому он всегда привлекал внимание ученых, занимающихся исследованиями сердечно-сосудистых заболеваний.

Ключевые слова: ЛХАТ; атеросклероз; липопротеины

61002, м. Харків, вул. Куликівська, 12.

Національний фармацевтичний університет 